\title{
Prospective Teachers' Educational Beliefs and Their Views about the Principles of Critical Pedagogy
}

\author{
Çağlar Kaya ${ }^{1} \&$ Sinem Kaya ${ }^{1}$ \\ ${ }^{1}$ Faculty of Education, Muğla Sttkı Koçman University, Muğla, Turkey \\ Correspondence: Çağlar Kaya, Muğla Sıtkı Koçman University, Faculty of Education, Muğla, Turkey. E-mail: \\ caglarkaya@mu.edu.tr
}

Received: May 19, 2017

Accepted: June 11, 2017

Online Published: July 5, 2017

doi:10.5539/jel.v6n4p181

URL: http://doi.org/10.5539/jel.v6n4p181

\begin{abstract}
The main idea behind this research is to determine prospective teachers' educational beliefs and their views about critical pedagogy. Therefore, the purpose of this research is to analyze the relationship between prospective teachers' educational beliefs and their views about critical pedagogy. In this study, "Educational Beliefs Scale" is used with the "Principals of Critical Pedagogy Scale". Based on the Educational Beliefs Scale, five theories on educational philosophy including: Perennialism, Essentialism, Progressivism, Reconstructionism, and Existentialism are examined. Besides Education System, Functions of School and the Emancipator School dimensions of the Principals of Critical Pedagogy Scale are analyzed. The research is conducted as a survey model study. The sample of the research comprises of 452 last grade undergraduate students from the different departments of Faculty of Education in Muğla Sitkı Koçman University. Descriptive statistics and Pearson Product Momentum Correlation was applied to the data.
\end{abstract}

Keywords: educational beliefs, principles of critical pedagogy, prospective teachers

\section{Introduction}

Philosophical perspectives and background of an education system may be open to discussion for all times. What should be taught to students? How should the decided curriculum be taught? Why should we teach our children and teenagers? Probably these questions do not have exact answers. So maybe this is one of the reasons of the occurrence of different philosophies of education in time. As Misirl (2009, pp. 35-36) states, philosophy of education tries to explain the thoughts, notions and principles that shape education. More profoundly, it examines the theoretical foundations of education and aims to evaluate the practices, needs and weaknesses of education. Considering this point of view, educators use the power of philosophy to question education and after they have a holistic perspective on the main goal of education. According to John Dewey philosophy of education can be explained as below:

"Since education is the process through which the needed transformation may be accomplished and not remain a mere hypothesis as to what is desirable, we reach a justification of the statement that philosophy is the theory of education as a deliberately conducted practice" (2001, p. 387).

Thus, it may be inferred that the theory of education leads the practice with the philosophy of education. As a result of involving philosophy in education, there may be found different educational philosophies in the literature (Ergün, 2013, p. 84; Gutek, 2014, p. 2). But in this research five main educational beliefs, based on main educational philosophies, are taken into account. So, these philosophies are determined as Perennialism, Essentialism, Progressivism, Reconstructionism and Existentialism.

As an educational philosophy, Perennialism uses idealism and realism as base. According to Perennialism the main problem of education should be making a curriculum based on the nature of human beings because the nature of human never changes and it is predictably stable. So, the models of education should be constant. The main goal of education must be training people with a strong personality. Thus, schools cannot be a copy of life, they must be the life itself (Ergün, 2013, pp. 84-85; Misırl, 2009, p. 44; Sönmez, 2015, p. 69).

The other educational philosophy, Essentialism, has some common points with different philosophies in the literature, but it is mostly based on idealism and realism like Perennialism. All generations must be trained according to the "essentials that all people must know" as to Essentialism. Thus, this creates a teacher oriented 
and subject based education system with an emphasis on memorization. So, teacher is a key factor of the learning process in schools and they almost should know everything to teach students in a proper way (Ergün, 2013, p. 87; Gutek, 2014, p. 289; Misirl1, 2009, p. 44; Sönmez, 2015, pp. 97-99).

The third educational philosophy of the research is Progressivism, which has its roots from pragmatism. Unlike Perennialism, Progressivism suggests that education should constantly reconstruct the experiences of students. So, learning environment should always be arranged according to the needs and interests of the students. Because of this idea, goals of education must be in dynamic change based on the cultural, social and technological developments. This point of view makes students as the center of learning process and teachers are only guides for the students. Therefore, problem solving is the key notion of education according to Progressivism (Cevizci, 2016, pp. 126-130; Ergün, 2013, pp. 85-86; Gutek, 2014, p. 324; Misırlı, 2009, p. 45; Sönmez, 2015, pp. 111-117).

Reconstructionism, based upon pragmatism, states that main task of education is to arrange and reshape society continuously. Providing peace and happiness for humanity, achieving to build civilization with socially accepted values and making the world a better place for living are the main goals of education. Hence, education is a tool for creating an ideal society and leading social reforms (Ergün, 2013, p. 87; Gutek, 2014, p. 340; Sönmez, 2015, pp. 117-120).

The last educational philosophy of the research, Existentialism, aims to teach students that liberty is above all the other things in life. It gives a lot of importance to improving one's individuality and so education should provide this opportunity. Creativity and liberty of a human being must be taken into consideration when arranging learning environments in schools (Gutek, 2014, pp. 135-136; Sönmez, 2015, pp. 150-156).

As the other main topic of this research, Critical Pedagogy, in other words critical theory of education, needs to be mentioned briefly. Although there is no agreement about who originated Critical Pedagogy (Duncan-Andrade \& Morrell, 2008, p. 24), Paulo Freire, a Brazilian educator, is considered as the "father of Critical Pedagogy" (Kirylo, 2013, p. 49). So, the basis of Critical Pedagogy is formed by the thoughts of Freire about education. According to him, there are two main approaches to education. One is banking education, which is based on a relationship between teachers who are narrative subjects and students who are listening objects of the learning process. This process of education means that students are some objects to be filled with knowledge and they only get what teachers dictate. In short, the more manageable and adaptable the students are, the better students they become (Freire, 2010, pp. 48-49).

According to banking education, the teacher teaches because s/he knows everything. Besides the teacher talks instead of students and disciplines the students. If the teacher makes a choice she/he enforces the choice to the students. The teacher chooses the program content and is the subject of the learning process (Freire, 2010, p. 50). On the other hand, as an antithesis to banking education, problem-posing education sees people as conscious human beings. So, the people are in the process of becoming liberated through cognitive acts, not the transformation of information (Freire, 2010, p. 56).

With these basic ideas in mind, Critical Pedagogy is considered as a praxis. So as a praxis, Critical Pedagogy cannot be still. It is always in a dynamic process of theorizing practice and practicing theory because it involves an evolving working relationship between theory and practice. This relationship must always be in progress because one without the other does not amount to praxis (Monchinski, 2008, p. 1). So, this back-and-forth dialectical process must be kept in mind while mentioning about Critical Pedagogy.

Other than Freire, there are many scholars who contribute to Critical Pedagogy literature such as Michael Apple, Antonia Darder, Henry Giroux, Antonio Gramsci, Ivan Illich, Joe L. Kincheloe, Peter McLaren and many others (Duncan-Andrade \& Morrell, 2008, p. 23; Kirylo, 2013). So, all these critical pedagogues have their own definition and view of Critical Pedagogy although they have some similarities inevitably. As Monchinski (2008, p. 2) states, "there is no trite, one or two sentence definition of Critical Pedagogy that explains what Critical Pedagogy is at all times for all people". This is because all descriptions of Critical Pedagogy are shaped by who devise them and the values they hold (Kincheloe, 2008, p. 7). So, it is useful to include different definitions of Critical Pedagogy from different pedagogues to understand better what Critical Pedagogy is.

Literally, Critical Pedagogy is a concept that argues problems of education and education system itself. The purpose of Critical Pedagogy is to signal how questions of audience, voice, power and evaluation actively work to construct schools into an environment where teachers and students can question the relationship between theory and practice, critical analysis and common sense, learning and social change. In this way Critical Pedagogy illuminates relationships among knowledge, authority and power (Giroux, 2013). It also examines 
schools in their historical context and accepts schools as part of the existing social and political environment. Thus, this characterizes schools for living in a class dominant society. Thus, Critical Pedagogy creates important opposing ideas to the positivistic, ahistorical, and depoliticized analysis by both liberal and conservative critics of schooling (McLaren, 2011, p. 273). Finally, Kincheloe (2008, p. 8) states some main characteristics of Critical Pedagogy. Basically, Critical Pedagogy is constructed on the belief that education is inherently political and it dedicates itself to the alleviation of human suffering.

According to Critical Pedagogy, the curriculum represents more than a program of study and classroom text. So critical educational theorists are concerned with outcomes of the curriculum in favor of dominant groups (McLaren, 2011, p. 312). So, every curriculum has its own philosophy behind and it is shaped with this philosophy. This idea makes critical educational theorists think on the practices of the curriculum according to the educational philosophies. Considering the literature available, it is seen that there is a reasonable amount of research on both educational beliefs (Alkın-Şahin, Tunca, \& Ulubey, 2014; Altınkurt, Yılmaz, \& Oğuz, 2012; Biçer, Er, \& Özer, 2013; Çoban, 2004; Doğanay \& Sarı, 2003; Duman, 2008; Hermans, Tondeur, van Braak, \& Valcke, 2008; Ilgaz, Bülbül, \& Çuhadar, 2013; Minor, Onwuegbuzie, Witcher, \& James, 2002; Oğuz, Altınkurt, Yılmaz, \& Hatipoğlu, 2014; Yılmaz, Altınkurt, \& Çokluk, 2011; Yılmaz \& Tosun, 2013) and views about/principles of Critical Pedagogy (McLaren, Martin, Farahmandpur, \& Jaramillo, 2004; Y1lmaz, 2009; Y1lmaz \& Altınkurt, 2011) with different variables and subjects in higher education. It is also possible to find many researches on critical thinking skills/levels of prospective teachers (Alkın-Şahin et al., 2014; Alper, 2010; Beşoluk \& Önder, 2010; Can \& Kaymakçı, 2015; Çiçek-Sağlam \& Büyükuysal, 2013; Ekinci \& Aybek, 2010; Emir, 2012; Kartal, 2012; Korkmaz, 2009; Tümkaya, 2011) but the researchers could not find sufficient research on relationship between educational beliefs and the principles of Critical Pedagogy. As a result, this motivation led the researchers doing this research on prospective teachers as one day they will teach in schools and what they believe or base their ideas about teaching is crucial for students.

\section{Method}

In the light of the literature, the main problem of the research is to understand the relationship between educational philosophies and Critical Pedagogy. Educational beliefs, which are shaped by the educational philosophies behind the curriculum, are used to understand the relationship between these two variables. So, with this purpose the research asks these main questions;

1) How is prospective teachers' level of agreement to educational beliefs and the principles of Critical Pedagogy?

2) Is there a correlation between prospective teachers' educational beliefs (Perennialism, Essentialism, Progressivism, Reconstructionism and Existentialism) and their views about the principles of Critical Pedagogy (Functions of Schools, Education System and Emancipator School)?

The research is designed as a general survey model research. The purpose of the research is to determine if educational philosophies like Perennialism, Essentialism, Progressivism, Reconstructionism and Existentialism are correlated with prospective teachers' views about critical pedagogy. It is possible to state that there are not many researches that examine these variables together.

Based on the prior studies and researches, it is expected that a tendency to Progressivism, Reconstructionism and Existentialism as educational philosophies would be positively related to the views about critical pedagogy. Especially, the researchers expect that beliefs about Existentialism would be a strongly correlated with the principles of Critical Pedagogy. On the other hand, it is expected that beliefs about Perennialism and Essentialism may be negatively related to views about critical pedagogy.

\subsection{Participant Characteristics}

The population of the relevant research was approximately 3500 undergraduate students, studying within different departments of the Faculty of Education in Muğla Sitkı Koçman University, during Spring Semester of the 2014-2015 Academic Year. So the sample (around 13\% of the population) of the research consisted of 452 students $(272 / 60.2 \%$ female, 180/39.8\% male) from different departments (Primary Education program: 91/20.1\%, Social Science Education program: 74/16.4\%, Science Education program: 59/13.1\%, Turkish Language Education program: 61/13.5\%, Psychological Counseling and Guidance program: 51/11.3\%, Preschool Education program: 44/9.7\%, Foreign Language Education department: 41/9.1\% and Fine Arts Education department: 31/6.9\%) of Muğla Sttkı Koçman University, Faculty of Education. Age range of the participants change between 20 and 35, arithmetic age average being $\bar{x}=22.60(\mathrm{Sd}=1.60)$. 


\subsection{Measures}

In this research two main scales were used to collect the data. "Educational Belief Scale" was used to determine prospective teachers' tendencies toward educational philosophies. Besides "The Principles of Critical Pedagogy Scale" was used to determine prospective teachers' views about critical pedagogy. These scales were applied to participants by choosing the classes randomly. The participants were asked whether they wanted to volunteer for taking a part in the research. The features of the scales are as follows:

The Principles of Critical Pedagogy Scale (PCPS): The scale was developed by Y1lmaz (2009) which aims to evaluate teachers' and prospective teachers' views about critical pedagogy. It is a five Likert-type (from "1: I certainly disagree" to "5: I certainly agree") scale. It consists of thirty-one items in total and has three subscales which are "Education System (15 items)", "Functions of schools (11 items)" and "Emancipator School (5 items)". It also has nine reversed items within the subscales. The Cronbach Alpha coefficient of the total scale is .75, while the values for "Education System Subscale", "Functions of Schools Subscale" and "Emancipator School Subscale" are respectively $.88, .78$ and .61 . The score range of the total scale is $31-155$ and higher scores from the scale indicate that to what extent the participants agree with the Principles of Critical Pedagogy. According to the construct validity results, factor loads of the scale items range between .31 and .80 . The total explained variance by the scale is $40 \%$ (Y1lmaz, 2009). The Cronbach Alpha coefficients of the total scale and subscales are as follows: "Total Scale of Principles of Critical Pedagogy: .66", "Education System: .75", "Functions of Schools: .70" and "Emancipator School: .60".

Educational Belief Scale (EBS): The scale was developed by Y1lmaz, Altınkurt and Çokluk (2011). The main purpose of the scale is to determine educational beliefs of teachers and prospective teachers. It is a five Likert type scale (from "1: I totally disagree" to " 5 : I totally agree") and consists of 40 items in total. The scale has five subscales which are "Perennialism (8 items)", "Essentialism (5 items)", "Progressivism (13 items)", "Reconstructionism (7 items)" and "Existentialism (7 items)" and there are no reversed items in the scale. The Cronbach Alpha coefficients of the subscales are stated as follows: "Perennialism: .70", "Essentialism: .70", "Progressivism: .91", "Reconstructionism: .81" and "Existentialism: .89". Item factor loadings of the scale range from .42 to .74 , corrected item-total correlations between .22 and .90 . A variance of approximately $50 \%$ is explained when by the sum of five different factors (Yilmaz et al., 2011). The Cronbach Alpha coefficients of Perennialism, Essentialism, Progressivism, Reconstructionism and Existentialism subscales for this research are respectively $.63, .77, .79, .70$ and .83 .

\section{Results}

The data collected for the research was analyzed with the help of SPSS 19.00 (Statistical Program for Social Sciences). Prior to analysis, the data collected from the questionnaires of seven students were eliminated from the analysis, because they had missing data. Histogram and normality assumptions were examined and found to be satisfactory. Skewness and Kurtosis values of the data were acceptable and are found as shown in Table 1. These analyses were applied to the data to understand the feasibility of the data for further analyses. For the analysis of the data, Pearson Product-Momentum Correlations matrix was used.

Table 1. Skewness and Kurtosis values of the scales and subscales

\begin{tabular}{lllll}
\hline \multirow{2}{*}{ Scales and Subscales } & \multicolumn{2}{c}{ Skewness } & \multicolumn{2}{c}{ Kurtosis } \\
\cline { 2 - 5 } & Statistic & Std. Error & Statistic & Std. Error \\
\hline Principles of Critical Pedagogy & .503 & .115 & .793 & .229 \\
Perennialism & -.144 & .115 & -.160 & .229 \\
Essentialism & .706 & .115 & .042 & .229 \\
Progressivism & -.779 & .115 & .303 & .229 \\
Reconstructionism & -.201 & .115 & -.136 & .229 \\
Existentialism & -1.322 & .115 & 1.232 & .229 \\
\hline
\end{tabular}

The findings of the research are revealed respectively according to the research questions. First, Table 2 below displays the descriptive statistics educational belief subscales and principles of Critical Pedagogy and its 
sub-scales (Education System, Functions of Schools and Emancipator School). After that, Table 3 is presented to show the findings on the correlations between educational beliefs and principles of Critical Pedagogy.

Table 2. Descriptive statistics of educational beliefs and principles of Critical Pedagogy

\begin{tabular}{lcccccccc}
\hline \multicolumn{1}{c}{ Variables } & $\mathrm{n}$ & $\mathrm{K}$ & Min. & Max. & $\bar{x}$ & Range & $\mathrm{S}$ & $\bar{x} / \mathrm{K}$ \\
\hline Perennialism & 452 & 8 & 17 & 40 & 30.06 & $8-40$ & 4.65 & 3.75 \\
Essentialism & 452 & 5 & 5 & 25 & 11.40 & $5-25$ & 4.26 & 2.28 \\
Progressivism & 452 & 13 & 38 & 65 & 57.08 & $13-65$ & 5.36 & 4.39 \\
Reconstructionism & 452 & 7 & 15 & 35 & 27.40 & $7-35$ & 3.88 & 3.91 \\
Existentialism & 452 & 7 & 22 & 35 & 32.44 & $7-35$ & 2.95 & 4.63 \\
Education System & 452 & 15 & 24 & 73 & 48.92 & $15-75$ & 8.70 & 3.26 \\
Functions of Schools & 452 & 11 & 19 & 54 & 33.45 & $11-55$ & 5.96 & 3.04 \\
Emancipator School & 452 & 5 & 9 & 25 & 20.33 & $5-25$ & 2.89 & 4.06 \\
Critical Pedagogy & 452 & 31 & 71 & 145 & 102.70 & $31-155$ & 12.34 & 3.31 \\
\hline
\end{tabular}

Table 2 shows the descriptive statistics of the prospective teachers' views about educational beliefs and principles of Critical Pedagogy. Prospective teachers' views about their educational beliefs are mostly stated as "I agree" with Perennialism ( $\bar{x}=30.06, \mathrm{~S}=4.65)$, Progressivism $(\bar{x}=57.08, \mathrm{~S}=5.36)$, Reconstructionism $(\bar{x}=27.40$, $\mathrm{S}=3.88)$ and Existentialism $(\bar{x}=32.44, \mathrm{~S}=2.95)$. On the other hand, participants "disagree" with Essentialism $(\bar{x}=11.40, \mathrm{~S}=4.26)$.

Additionally, the participants mostly state "Moderately agree" with the sub-scales like the education system $(\bar{x}=48.92, \mathrm{~S}=8.70)$ and the functions of schools $(\bar{x}=33.45, \mathrm{~S}=5.96)$. This situation is the same with the principles of Critical Pedagogy total score $(\bar{x}=102.70, \mathrm{~S}=12.34)$ while they state that they just "Agree" with the emancipator school sub-scale $(\bar{x}=20.33, \mathrm{~S}=2.89)$.

Table 3. The correlations between educational beliefs and principles of Critical Pedagogy

\begin{tabular}{|c|c|c|c|c|c|c|c|c|}
\hline Variables & 1 & 2 & 3 & 4 & 5 & 6 & 7 & 8 \\
\hline 1. Perennialism & 1 & & & & & & & \\
\hline 2. Essentialism & $.26^{*}$ & 1 & & & & & & \\
\hline 3. Progressivism & $.15^{*}$ & $-.34 * *$ & 1 & & & & & \\
\hline 4. Reconstructionism & $.36^{*}$ & .04 & $.35^{*}$ & 1 & & & & \\
\hline 5. Existentialism & .03 & $-.40 * *$ & $.55^{*}$ & $.29 *$ & 1 & & & \\
\hline 6. Education System & .07 & .08 & .01 & $.10^{* *}$ & -.01 & 1 & & \\
\hline 7. Functions of Schools & $.25^{*}$ & $.49 *$ & $-.17 * *$ & $.16^{*}$ & $-.24 * *$ & $.17 *$ & 1 & \\
\hline 8. Emancipator School & $.26^{*}$ & -.03 & $.42 *$ & $.38^{*}$ & $.34 *$ & $.11^{* *}$ & $.27 *$ & 1 \\
\hline 9. Critical Pedagogy & $.23 * *$ & $.29 * *$ & .02 & $.24 * *$ & -.03 & $.81^{* *}$ & $.66^{* *}$ & $.45^{* *}$ \\
\hline
\end{tabular}

The findings on Table 3 indicate that education system, as a critical pedagogy principle, is positively correlated only with Reconstructionism ( $\mathrm{r}=.10, \mathrm{p}<.005)$ within educational beliefs. Functions of schools, as another critical pedagogy principle, is positively correlated with Perennialism $(\mathrm{r}=.25, \mathrm{p}<.001)$, Essentialism $(\mathrm{r}=.49, \mathrm{p}<.001)$ and Reconstructionism $(\mathrm{r}=.16, \mathrm{p}<.001)$. Emancipator school principle of Critical Pedagogy is positively correlated with Perennialism $(\mathrm{r}=.26, \mathrm{p}<.001)$, Progressivism $(\mathrm{r}=.42, \mathrm{p}<.001)$, Reconstructionism $(\mathrm{r}=.38, \mathrm{p}<.001)$ and Existentialism $(\mathrm{r}=.34, \mathrm{p}<.001)$. Critical Pedagogy total score is positively correlated with Perennialism $(\mathrm{r}=.23$, $\mathrm{p}<.001)$, Essentialism $(\mathrm{r}=.29, \mathrm{p}<.001)$ and Reconstructionism $(\mathrm{r}=.24, \mathrm{p}<.001)$. 


\section{Discussion}

One of the two main purposes of the current study were to determine prospective teachers' views about the principles of Critical Pedagogy along with to understand how prospective teachers' educational beliefs were. The other main purpose was to determine if prospective teachers' educational beliefs (Perennialism, Essentialism, Progressivism, Reconstructionism and Existentialism) are correlated with their views about the principles of Critical Pedagogy (functions of schools, education system and emancipator school). Results are presented below according to the main purposes of the research by discussing with related literature.

The results of the study show that participants are tended to agree with educational beliefs within different philosophical perspectives such as Perennialism, Progressivism, Reconstructionism and Existentialism. This result shows similarity with some researches in the related literature (Altınkurt et al., 2012; Biçer et al., 2013; Çoban, 2004; Doğanay \& Sarı, 2003; Duman, 2008; Yılmaz \& Tosun, 2013). On the other hand, only Essentialism seems to be non-preferred by the participants as there may be found similar results because some researches state that Essentialism is the least preferred educational belief amongst others (Alkın-Şahin et al., 2014; Altınkurt et al., 2012; Biçer et al., 2013; Ilgaz et al., 2013; Oğuz et al., 2014; Yılmaz \& Tosun, 2013).

Perennialism and Essentialism are considered as classic educational philosophies while the others are called contemporary (Ergün, 2013; Misirl1, 2009; Tuncel, 2004). So it is expected that the participants would show a tendency to agree with contemporary philosophies of education. As Ilgaz, Bülbül, and Çuhadar (2013) state that prospective teachers' educational philosophies tend to be mostly contemporary ones. Besides more contemporary teacher beliefs about the practice of teaching provides more constructivist practices in the classroom and this may help to build more contemporary implications in education (Hermans et al., 2008). But according to results, Perennialism is one the educational philosophies that students tend to agree with. Actually, some researchers found that prospective teachers tend to agree with Perennialism on a high level (Biçer et al., 2013). This distribution between the educational beliefs may be interpreted as an impact of participants' educational backgrounds, arising from their different learning experiences because educational beliefs are based on educational philosophies which are considered as one's systematic ideas and conceptions that orients educational practices. Besides, implied ideas and conceptions are shaped by many variables such as with whom the students study, what readings they had done before, by whom they were raised and many other factors. As Minor, Onwuegbuzie, Witcher, and James (2002) state, educational beliefs of teachers may have a gender and cultural context. So, it an important factor on identifying teachers' beliefs.

As another result, participants "moderately agree" with the principles of Critical Pedagogy. They also moderately agree with the principle of education system, the principle of functions of the school. But when it comes to the principle of emancipator school participants tend to show an above moderate agreement with emancipatory characteristics of schools. So, it is possible to state that participants think of schools as the places where students are emancipated. This result shows some similarities with the study of Yllmaz (2009) which has a different sample, conducted with teacher elementary school teachers. According to Yilmaz (2009) teachers mostly agree with functions of schools sub-scale, but in this research we found that prospective teachers mostly agree with the emancipator school sub-scale and this may be because of the differences between samples of the researches.

According to the results, Perennialism, Essentialism and Reconstructionism are correlated with the principles of Critical Pedagogy. This result is a surprising one for the researchers because Essentialism and Perennialism considered as a conventional philosophy, but they are found to be related with students' views of Critical Pedagogy. As stated before, the other contemporary philosophies like Progressivism and Existentialism were expected to be related with Critical Pedagogy as they emphasize more emancipating ideas. According to some researches critical thinking levels of prospective teachers are on a moderate level (Alper, 2010; Beşoluk \& Önder, 2010; Korkmaz, 2009). This means that prospective teachers are not weak, but they are not strong on critical thinking skills either. So this finding on critical thinking may be linked to the views about the principle of Critical Pedagogy. In addition, Kartal (2012) indicates that prospective teachers' critical thinking skills are above moderate while the opposite is stated by Can and Kaymakçı (2015) and Alkın-Şahin, Tunca, and Ulubey (2014) as they say that critical thinking tendencies of prospective teachers are low.

As it is seen there some opposite researches on prospective teachers' tendencies about critical thinking. This may result from the cultural differences mentioned above. These differences are called as obstacles on critical thinking and "the traditional approach to education" or "the ongoing practice of rote learning" are regarded as the main obstacles to critical thinking (Çiçek-Sağlam \& Büyükuysal, 2013). So, removing these obstacles is considered as one of the main solutions for the positive futures of the teachers. Students should graduate having the skill of critical thinking before becoming a teacher (Emir, 2012). There are some suggestions on the 
acquisition of critical thinking skills, like every faculty of education in Turkey should put critical thinking courses at every department that trains prospective teachers (Ekinci \& Aybek, 2010) because it is stated that there is a positive relationship between academic success and critical thinking skills (Tümkaya, 2011). Even these suggestions on Critical Pedagogy may help prospective teachers gain critical thinking skills or not, but probably it would help them to gain different perspectives on education and thus they would be able to construct an eclectic philosophy of education, which is considered to be more beneficial and practical.

The principle of emancipator school is meaningfully correlated with Reconstructionism, Perennialism, Progressivism and Existentialism. This result may be related to the work of Alkın-Şahin et al. (2014) as they state that there is a positive and moderate level of relationship between Existentialism and critical thinking while this positive relationship between Reconstructionism, Perennialism and critical thinking is at low level. So this result can be considered as consistent with the literature as well.

Essentialism, Reconstructionism and Perennialism are found to be meaningfully correlated with the principle of functions of the schools. Essentialism itself has the highest correlation with the functions of schools principle of Critical Pedagogy. This result for emancipator school sub-scale is surprising because in the related literature (Alkın-Şahin et al., 2014) the situation is the opposite. There is a negative relationship between critical thinking tendencies and Essentialist views of prospective teachers. Because of its nature, Essentialism tends to hold opposite ideas to the philosophy of Critical Pedagogy and the same idea goes for Perennialism. So, it is hard for the researchers to explain the connection between Essentialism, Perennialism and Critical Pedagogy. It may be linked to some conventional implications in some part of education system in Turkey.

Finally, for the principle of education system is correlated with Reconstructionism as expected, but on a really low level. This result can be related to the findings of Hermans, Tondeur, van Braak, and Valcke (2008) as they suggest that constructivist teacher beliefs about the practice of teaching are strongly related with an innovative classroom. In addition to this, there is a low level and positive relationship between Reconstructionism and critical thinking skills of prospective teachers (Alkın-Şahin et al., 2014). So, this low level connection is considered as normal.

Some recommendations in the interest of researchers are as follows: (1) Prospective teachers agree with educational beliefs. This makes us think that critical thinking abilities causes them to agree with educational beliefs. However, research results show us, even though prospective teachers highly accept educational beliefs, their levels of views about Critical Pedagogy are moderate. Based on this result, further researches should be made deeply within focus groups, interview methods, etc. After all we may have a deeper information about the issue. Thus, researchers can know deeply what needs to be done to improve prospective teachers' positive views about principles of Critical Pedagogy. So, researchers can understand more clearly why prospective teachers agree with different philosophical perspectives. (2) A holistic approach, such as researches on academic stuff in universities and researches on any fields of educational practices, would enlighten how to improve views about principles of Critical Pedagogy.

Recommendations for practitioners are as follows: (1) Prospective teachers' tendencies to Critical Pedagogy approach is not satisfactory in this research and many other researches. This result needs to be paid attention while structuring politics of education. (2) More opportunities may be created within the curriculum with an aim of improving Critical Pedagogy perspectives of prospective teachers. So, Critical Pedagogy may have its emphasized place during in service training.

Although the sample of this research may be considered as strong, collecting data process was conducted only in Muğla Sitkı Koçman University, Faculty of Education. This is considered as a limitation for this research. Conducting a similar research on different samples will enrich the literature of educational beliefs and critical pedagogy on prospective teachers.

\section{Acknowledgments}

An initial presentation of this research was given at ISNITE 2015 (International Symposium, New Issues on Teacher Education), held at the University of Thessaly in Greece. 


\section{References}

Alkın-Şahin, S., Tunca, N., \& Ulubey, Ö. (2014). Öğretmen adaylarının eğitim inançları ile eleştirel düşünme eğilimleri arasındaki ilişki [The relationship between pre-service teachers' educational beliefs and their critical thinking tendencies]. Elementary Education Online, 13(4), 1473-1492.

Alper, A. (2010). Critical thinking disposition of pre-service teachers. Education and Science, 35(158), 14-27. Retrieved from http://eb.ted.org.tr/index.php/EB/article/view/153/218

Altınkurt, Y., Yılmaz, K., \& Oğuz, A. (2012). İlköğretim ve ortaöğretim okulu öğretmenlerinin eğitim inançları [Educational beliefs of primary and secondary school teachers]. Ondokuz Mayls Üniversitesi Ĕgitim Fakultesi Dergisi, 31(2), 1-19.

Beşoluk, Ş., \& Önder, İ. (2010). Öğretmen adaylarının öğrenme yaklaşımları, öğrenme stilleri ve eleştirel düşünme eğilimlerinin incelenmesi [Investigation of teacher candidates' learning approaches, learning styles and critical thinking dispositions]. Elementary Education Online, 9(2), 679-693. Retrieved from http://dergipark.ulakbim.gov.tr/ ilkonline/ article/view/5000038065/5000036922

Biçer, B., Er, H., \& Özel, A. (2013). Öğretmen adaylarının epistemolojik inançları ve benimsedikleri eğitim felsefeleri arasındaki ilişki [The relationship between the epistemological beliefs and educational philosophies of the teacher candidates adopted]. Journal of Theory and Practice in Education, 9(3), 229-242. Retrieved from http://eku.comu.edu.tr/article/view/1044000193/1044000240

Can, Ş., \& Kaymakçı, G. (2015). Öğretmen adaylarının eleştirel düşünme eğilimleri [Pre-service teachers' critical thinking tendencies]. NWSA-Education Sciences, 9(6), 66-83. https://doi.org/10.12739/nwsa.2015.10.2.1c0633

Cevizci, A. (2016). Eğitim felsefesi. Ankara: Say Yayınları.

Çiçek-Sağlam, A., \& Büyükuysal, E. (2013). Eğitim fakültesi son sınıf öğrencilerinin eleştirel düşünme düzeyleri ve buna yönelik engellere ilişkin görüşleri [Critical thinking levels of senior students at education faculties and their views on obstacles to critical thinking]. Journal of Human Sciences, 10(1), 258-278. Retrieved from https://www.j-humansciences.com/ojs/index.php/IJHS/article/view/2459/1057

Çoban, A. (2004). Sınıf öğretmenlerinin eğitim sürecine ilişkin felsefi tercihlerini değerlendirme [Evaluation on classroom teachers' philosophical preferences in educational process]. In XIII. Ulusal Eğitim Bilimleri Kurultayl (pp. 1-11). İnönü Üniversity, Faculty of Education, $6^{\text {th }}-9^{\text {th }}$ of July, Malatya. Retrieved from https://pegem.net/dosyalar/dokuman/ 82033112.pdf

Dewey, J. (2001). Democracy and education [Adobe Acrobat Reader version]. Retrieved from http://ibrary.um.ac.id/images/stories/ebooks/Juni10/democracy\%20and\%20education\%20-\%20john\%20de wey.pdf

Doğanay, A., \& Sarı, M. (2003). İlköğretim öğretmenlerinin sahip oldukları eğitim felsefelerine ilişkin algılarının değerlendirilmesi "öğretmenlerin eğitim felsefeleri” [Evaluation of elementary school teachers' perceptions of educational philosophies, educational philosophies of teachers]. Türk Eğitim Bilimleri Dergisi, 1(3), 321-337. Retrieved from http://www.tebd.gazi.edu.tr/index.php/tebd/article/view/141/128

Duman, B. (2008). Öğrencilerin benimsedikleri eğitim felsefeleriyle kullanıldıkları öğrenme strateji ve öğrenme stillerinin karşılaştırılması. Çukurova Üniversitesi Sosyal Bilimler Enstitüsü Dergisi, 17(1), 203-224. Retrieved from http://dergipark.ulakbim.gov.tr/ cusosbil/article/view/5000001252/5000001943

Duncan-Andrade, J. M. R., \& Morrell, E. (2008). The art of critical pedagogy: Possibilities for moving from theory to practice in urban schools. New York: Peter Lang.

Ekinci, Ö., \& Aybek, B. (2010). Öğretmen Adaylarının Empatik ve Eleştirel Düşünme Eğilimlerinin İncelenmesi [Analysis of the empathy and the critical thinking disposition of the teacher candidates]. Ilkögretim Online, 9(2), 816-827. Retrieved from http://dergipark.ulakbim.gov.tr/ilkonline/article/view/5000038076/5000036933

Emir, S. (2012). Eğitim fakültesi öğrencilerinin eleştirel düşünme eğilimleri. Hasan Ali Yücel Egitim Fakültesi Dergisi, $\quad 9(1), \quad 34-57 . \quad$ Retrieved from http://www.journals.istanbul.edu.tr/iuayefd/article/view/1023017929/1023017166

Ergün, M. (2013). Eğitimin felsefi temelleri. In Ö. Demirel, \& Z. Kaya (Eds.), Eğitim bilimine giriş (pp. 67-94). Ankara: Pegem Akademi. 
Freire, P. (2010). Ezilenlerin pedagojisi [Pedagogy of the Oppressed] (Trans. into Turkish by D. Hattatoğlu, \& E. Özbek). İstanbul: Ayrıntı Yayınları.

Giroux, H. A. (2013, January 30). Interview by J. M. B. Tristán [Online magazine article]. In A critical interview with Henry Giroux, Global Education Magazine. Retrieved from http://www.globaleducationmagazine.com/critical-interview-henry-giroux/

Gutek, G. L. (2014). Eğitime felsefi ve ideolojik yaklaşımlar [Philosophical and ideological perspectives on education] (Trans. into Turkish by N. Kale). Ankara: Ütopya Yayınevi.

Hermans, R., Tondeur, J., van Braak, J., \& Valcke, M. (2008). The impact of primary school teachers' educational beliefs on the classroom use of computers. Computers \& Education, 51(4), 1499-1509. https://doi.org/10.1016/j.compedu.2008.02.001

Ilgaz, G., Bülbül, T., \& Çuhadar, C. (2013). Öğretmen adaylarının eğitim inançları ile öz-yeterlik algıları arasındaki ilişkinin incelenmesi [Investigation of the relationship between preservice teachers' educational beliefs and their perceptions of self-efficacy]. Abant İzzet Baysal Üniversitesi Eğitim Fakültesi Dergisi, 13(1), 50-65. Retrieved from http://dergipark.ulakbim.gov.tr/aibuefd/article/view/5000091467/ 5000084839

Kartal, T. (2012). İlköğretim fen bilgisi öğretmen adaylarının eleştirel düşünme eğilimlerinin incelenmesi [Exploring of dispositions toward critical thinking in pre-service elementary science teachers]. Ahi Evran Üniversitesi Kırşehir Eğitim Fakültesi Dergisi (KEFAD), 13(2), 279-297. Retrieved from http://dergipark.ulakbim.gov.tr/aeukefd/article/view/5000086889/5000080818

Kincheloe, J. L. (2008). Knowledge and critical pedagogy. Springer. https://doi.org/10.1007/978-1-4020-8224-5

Kirylo, J. D. (2013). Paulo Freire: "Father" of critical pedagogy. In J. D. Kirylo (Ed.), A critical pedagogy of resistance: 34 pedagogues we need to know (pp. 48-52). Rotterdam: Sense Publishers. https://doi.org/10.1007/978-94-6209-374-4_13

Korkmaz, Ö. (2009). Öğretmenlerin eleştirel düşünme eğilim ve düzeyleri [Teachers' critical thinking level and dispositions]. Ahi Evran Üniversitesi Kırşehir Eğitim Fakültesi Dergisi (KEFAD), 10(1), 1-13. Retrieved from http://dergipark.ulakbim.gov.tr/aeukefd/article/view/5000086416/5000080370

McLaren, P. (2011). Okullarda yaşam: Eleştirel pedagojiye giriş [An introduction to critical pedagogy in the foundations of education] (Trans. into Turkish by M. Y. Eryaman, \& H. Arslan). Ankara: Anı Yayıncılık.

McLaren, P., Martin, G., Farahmandpur, R., \& Jaramillo, N. (2004). Teaching in and against the empire: Critical pedagogy as revolutionary praxis. Teacher Education Quarterly, 31(1), 131-153. Retrieved from https://eric.ed.gov/?id=EJ795238

Minor, L. C., Onwuegbuzie, A. J., Witcher, A. E., \& James, T. L. (2002). Preservice teachers' educational beliefs and their perceptions of characteristics of effective teachers. The Journal of Educational Research, 96(2), 116-127. https://doi.org/10.1080/00220670209598798

Mısırlı, A. M. (2009). Eğitimin felsefi temelleri. In A. Tanrı̈ğen, \& R. Sarpkaya (Eds.), Eğitim bilimine giriş (pp. 25-52). Ankara: Anı Yayınc1lı.

Monchinski, T. (2008). Critical pedagogy and the everyday classroom. Springer. https://doi.org/10.1007/978-1-4020-8463-8_4

Oğuz, A., Altınkurt, Y., Yılmaz, K., \& Hatipoğlu, S. (2014). Öğretmenlerin eğitim inançları ile öğrenen özerkliğini destekleme davranışları arasındaki ilişki [The relationship between teacher's educational beliefs and support learner autonomy behavior]. Turkish Journal of Educational Studies, 1(1), 22-51. Retrieved from http://journals.firat.edu.tr/index.php/turk-jes/article/view/11/11

Sönmez, V. (2015). Eğitim felsefesi. Ankara: Anı Yayıncılık.

Tümkaya, S. (2011). Fen bilimleri öğrencilerinin eleştirel düşünme eğilimleri ve öğrenme stillerinin incelenmesi. Ahi Evran Üniversitesi Eğitim Fakültesi Dergisi, 12(3), 215-234. Retrieved from http://dergipark.gov.tr/download/article-file/15459

Tuncel, G. (2004). Öğretmenlerin kendi eğitim felsefelerini inşa etmeleri üzerine. Kâzım Karabekir Eğitim Fakültesi Dergisi, $10, \quad 223-242 . \quad$ Retrieved http://e-dergi.atauni.edu.tr/ataunikkefd/article/view/1021003962/1021003785

Y1lmaz, K. (2009). Elementary school teachers' views about the critical pedagogy. The Asia-Pacific Education Researcher, 18(1), 139-149. https://doi.org/10.3860/taper.v18i1.1042 
Yılmaz, K., \& Altınkurt, Y. (2011). Öğretmen adaylarının eleştirel pedagoji ile ilgili görüşleri. Ahi Evran Üniversitesi Eğitim Fakültesi Dergisi, 12(3), 195-213. Retrieved from http://dergipark.gov.tr/download/article-file/15458

Yılmaz, K., \& Tosun, M. F. (2013). Öğretmenlerin eğitim inançları ile öğretmen öğrenci ilişkilerine yönelik görüşleri arasındaki ilişki [Relationship between teachers' educational belief and their views about teacher-student relationships]. Journal of Education and Instruction Research, 2(4), 205-218. Retrieved from http://www.jret.org/FileUpload/ks281142/File/23.yilmaz.pdf

Yılmaz, K., Altınkurt, Y., \& Çokluk, O. (2011). Developing the educational belief scale: The validity and reliability study. Educational Sciences: Theory and Practice, 11(1), 343-350. Retrieved from http://files.eric.ed.gov/fulltext/EJ919905.pdf

\section{Copyrights}

Copyright for this article is retained by the author(s), with first publication rights granted to the journal.

This is an open-access article distributed under the terms and conditions of the Creative Commons Attribution license (http://creativecommons.org/licenses/by/4.0/). 